Biografistyka Pedagogiczna

Rok 3 (2018) nr 1

ISSN 2543-6112; e-ISSN 2543-7399

DOI: $10.36578 /$ BP.2018.03.06

Helena Głogowska*

\title{
Księża Białorusini w II Rzeczypospolitej - patrioci czy nacjonaliści?
}

\section{Belarusian Priests in Interwar Poland: Patriots or Nationalists?}

\begin{abstract}
After World War I, a range of territories inhabited largely by Belarusians, a religiously diverse group whose members included Roman Catholics, became part of interwar Poland. Catholic priests originating from this ethnic group (including Kostanty Stepowicz, Jan Siemaszkiewicz, Wiktor Szutowicz, Wincenty Godlewski, Adam Stankiewicz, and Władysław Tołłoczko) preached sermons in Belarusian, which sparked protest from the Church authorities. Before World War I, still in the Russian Empire, they had been associated with the Belarusian Catholic periodical Belarus (1913-1915) which advocated the idea of Belarusian national rebirth. In interwar Poland, the Church authorities, particularly the archbishop of Wilno, Romuald Jałbrzykowski, was adverse to the involvement of Catholic priests in the Belarusian national movement, especially in Belarusian Christian Democracy, and opposed preaching in Belarusian. Although they were Belarusian patriots, the Church authorities treated them as nationalists or even communists. Their choice to self-identify as Belarusians earned them persecution on the part of the Polish authorities, including searches, arrests, imprisonment and transfer to Polish-language parishes. We could ask why in ethnically-diverse interwar Poland these Belarusian priests were treated as enemies of the state, why they were forbidden to preach in the language of their local parishioners, why they were not allowed to collaborate with the Belarusian Christian Democratic press (Krinitsa Belarusskaya Krinitsa, Christianskaya Dumka) coming out in Wilno, and why they were sent on missions or transferred to other parishes. Those who survived World War II and

* Helena Głogowska - dr hab., profesor na Uniwersytecie Kazimierza Wielkiego w Bydgoszczy, lenabia@interia.pl.
\end{abstract}


found themselves in postwar Poland carefully concealed their national identity, faithfully serving the Catholic Church (for example Rev. Jan Siemaszkiewicz).

Keywords: interwar Poland, Belarusians, patriotism, Kostanty Stepowicz, Jan Siemaszkiewicz, Wincenty Godlewski, Adam Stankiewicz

Wraz z rodzącym się na początku XX w. w Imperium Rosyjskim białoruskim ruchem narodowym ujawniło się jego zróżnicowanie wyznaniowe. Dotychczas w niektórych opracowaniach uważa się, że białoruski ruch narodowy zaczął się tworzyć w środowisku katolickiej szlachty. Mimo wielu odmiennych opinii na ten temat faktem jest, że jeszcze przed pierwszą wojną światową wśród duchowieństwa rzymskokatolickiego w imperium rosyjskim pojawili się aktywni księża o wyraźnej białoruskiej opcji narodowej. Przejawem tego była chociażby białoruska gazeta katolicka „Biełarus”, wydawana w Wilnie w latach 1913-1915'. W latach 1906-1917 ukazało się w Wilnie 20 wydawnictw katolickich w języku białoruskim, był wśród nich m.in.: modlitewnik Boh z nami (Wilno 1915) ks. Bolesława Poczopki.

Ks. Adam Stankiewicz, autor pracy Biełaruski chryścijanski ruch (Wilno 1939), wymienił wśród księży Białorusinów biskupa sufragana diecezji mohylewskiej Stefana Danisewicza (1836-1913), który w latach 1906-1907 wprowadzał do życia religijnego Białorusinów ich język ojczysty, wydając katechizmy i zachęcając duchowieństwo do używania języka białoruskiego w parafiach białoruskich. Sam również często głosił kazania w tym języku². Pod wpływem jego oraz profesora Bronisława Epimacha-Szypiłły (wykładowcy Katolickiej Akademii Duchownej) w Petersburgu powstało koło białoruskie, które zrzeszało studentów pochodzących z ziem białoruskich. Byli wśród nich ks. Franciszek Budźka (1884-1920) i ks. Adam Lisowski (1884-1929).

Ks. Franciszek Budźka, pochodzący z Woznowszczyzny (powiat wilejski), był w Akademii w latach 1901-1902 i 1904-1905. Jego białoruskość była na tyle wyrazista, że władze duchowne (o polskiej orientacji narodowej) nie chciały wyświęcać go na księdza. Służył on na Połocczyźnie i Lepelszczyźnie, gdzie głosił

1 B. Poczopko, „Biełarus” (Ze wspomnień redaktora), „Przegląd Wileński”, nr 16, 11 października 1925, s. 3-5.

2 Ju. Turonak, Z paczynu prałata S'ciafana Danisiewicza, w: tenże, Madernaja historyja Biełarusi, Wilnia 2006, s. 145; A. Stankiewicz, Rodnaja mowa u'swiatyniach, Wilnia 1929, S. 72-75. 
kazania w języku białoruskim, uczył dzieci katechizmu po białorusku oraz szerzył białoruską świadomość narodową. Jego staraniem ukazały się Katechizm, Święty Andrzej Bobola, Historia Święta, Obrzędy kościelne w języku białoruskim $^{3}$. On także wspomagał pismo „Biełarus”.

Ks. Adam Lisowski, urodzony w Karandach (powiat oszmiański), przebywał w Akademii Duchownej w latach 1903-1906. W tym czasie był już świadomym Białorusinem i szerzył świadomość białoruską wśród studentów Akademii. Jak świadczył ks. Adam Stankiewicz, wówczas listy do ojca pisał w języku białoruskim, a latem jadąc na wieś w rodzinne strony, wiózł Dudkę białoruską Franciszka Bohuszewicza i katechizmy w języku białoruskim, a następnie rozdawał je chłopom ${ }^{4}$. W ten sposób zjednał sobie młodzież wiejską, siejąc wśród niej białoruską świadomość narodową.

W tym samym czasie w Akademii byli także ksiądz prałat Henryk Betto (1886-1965) oraz ks. Franciszek Hrynkiewicz (1884-1933). W seminarium duchownym w Petersburgu kształcili się wówczas przyszli księża z Białorusi: Jan Mamysz z Mińszczyzny (zmarł 8 stycznia 1913 r.) oraz Andrej Astramowicz z Oszmiańszczyzny (pseudonim literacki Andrej Ziaziula - 1878-1921), którzy już jako seminarzyści wiele robili dla białorutenizacji Kościoła rzymskokatolickiego.

Antoni Łuckiewicz, białoruski działacz narodowy zastanawiał się nad fenomenem księży Białorusinów:

Czy to księża litewscy dają dobry przykład, czy katolickie władze duchowne umieją patrzeć do przodu - w przyszłość - dalej za prawosławnych, trudno jednoznacznie powiedzieć. Jedno tylko widzimy: wśród młodych księży (zwłaszcza uczących się), którzy wyszli ze wsi i nie oderwali się od niej zupełnie, trafiają się coraz bardziej, i bardziej świadomi patrioci białoruscy. Gdzie niegdzie - często ze strachem przed bliższymi przełożonymi - zaczęli już głosić w kościele kazania po białorusku, wydają katechizmy i książki religijne w języku białoruskim itd. Wszyscy oni są księżmi-narodnikami, ludźmi, którzy poprzez własne sprawy religijne i idee umieją widzieć żywy naród; są to księża-obywatele swego kraju. Ale obok nich wśród duchowieństwa katolickiego jest jeszcze inny kierunek: przedstawiciele jego, poczynając od byłego biskupa wileńskiego barona Roppa, patrzą na język białoruski tylko jak na sposób szerzenia swych myśli wśród ludu. Takich

3 Ju. Turonak, Z paczynu prałata S'ciafana Danisiewicza, s. 451-453.

4 A. Stankievič, Biełaruski chryścijanski ruch, Vilnia 1939, s. 41. 
dalekowzrocznych polityków, jednak, jest mało: na Białorusi przeważają dotychczas księża-Polacy, i ich nacjonalizm polski nawet nie dopuszcza myśli, by, pracując dla katolicyzmu, duchowieństwo mogło posługiwać się językiem białoruskim, podtrzymując tym samym niesympatyczny dla Polaków białoruski ruch narodowy ${ }^{5}$.

Ważną rolę w ruchu białoruskim odegrał ks. Franciszek Hrynkiewicz z Nowego Dworu na Białostocczyźnie, który po naukach w Seminarium Duchownym w Wilnie, Akademii Duchownej w Petersburgu oraz po studiach w Innsbrucku i Monachium w 1909 r. rozpoczął służbę w Grodnie, gdzie został prefektem gimnazjum. W tym mieście byli wówczas księża Białorusini: Rodźka i Barouka oraz ks. dziekan Juliusz Ellert. Ks. Hrynkiewicz, nauczając religii w szkołach grodzieńskich, rozwinął działalność białoruską wśród uczniów, tworząc Horadzieński Hurtok Biełaruskaj Moładzi ${ }^{6}$. Wspomagał materialnie też pismo „Biełarus”, pisał doń oraz namawiał do pisania w nim ks. Władysława Tołłoczko (1887-1942). Po pierwszej wojnie światowej jednak ks. Hrynkiewicz odszedł od ruchu białoruskiego, nadal pozostając w Grodnie ${ }^{7}$.

Przed pierwszą wojną światową w Seminarium Duchownym w Wilnie ujawnili się także przyszli księża Białorusini - sprzyjała temu sytuacja w imperium rosyjskim po 1905 r. oraz obecność ruchu białoruskiego w Wilnie, zwłaszcza środowiska skupionego wokół gazety „Nasza Niva” oraz wydawnictw białoruskich, np.: Dudka i Smyk Franciszka Bohuszewicza. Wśród nich można wymienić J. Każarnowicza (wyświęconego w 1887 r.), Kazimierza Buraka (1900), Aleksandra Chadykę (1905), H. Chwasteckiego (1907), F. Hrynkiewicza (1907), Jana Siemaszkiewicza (1907), Franciszka Romejko (1909), Władysława Tołłoczko (1909), W. Rodźko (1910), J. Barouka (1910), Michała Piotrowskiego (1912) ${ }^{8}$. Ks. Adam Stankiewicz zwracał uwagę, że byli oni „bardziej lub mniej świadomymi Białorusinami”:

Wiemy o tym od nich samych, od ich kolegów i znajomych, a także wiemy o niektórych na podstawie ich działalności. Zwracamy na to szczególną uwagę, bo, być może, przyszły historyk, badając te sprawy, spotka gdzieś

5 A. Nawina, Na darozie da nowaha życ'cia, „Maładaja Biełarus”, 1912, nr 1, s. 2.

6 Jan z-pad Łasosny, Horadzienski Biełaruski Hurtok 1913 h. (Uspaminy), „Krywicz”, 1927, nr 1 (7), s. 64-65; L. S.-Sz., Uspaminy ab „Horadzienskim Hurtku biełaruskaj Moładzi”, „Studenskaja dumka”, 1925, nr 3, s. 28-31; nr 4, s. 31-34.

7 A. Stankievič, Biełaruski chryścijanski, s. 45-56.

8 Tamże, s. 59. 
w archiwach seminarium, czy konsystorza katolickiego, czy gdzieś w innym miejscu oficjalny zapis narodowości tych osób i w tym zapisie może zobaczyć wielu z nich jako Polaków. Otóż trzeba wiedzieć, że z powodu wspomnianych politycznych i częściowo religijnych przyczyn władze seminaryjne nie radziły klerykom wpisywać narodowości białoruskiej i nawet nie pozwalały. Świadczą o tym niektórzy sami klerycy z tych czasów. Dlatego niemal wszyscy klerycy-Białorusini zapisywali się wtedy jako Polacy ${ }^{9}$.

Ks. Stankiewicz, który naukę w seminarium duchownym w Wilnie podjął w 1910 r., wspominał:

Przybyłem do seminarium już jako całkiem świadomy Białorusin. Różnicę narodowościową od Polaków odczuwałem i rozumiałem bez żadnych ogródek i trudności. Początkowo trochę trudniej było mi odróżnić swą odrębność białoruską od rosyjskiej. Szkoła rosyjska, która nauczyła, że wszyscy ruscy dzielą się na trzy gałęzie - wielkorusów, małorusów i białorusów, zrobiła swoje. Mojemu młodemu rozumowi było to początkowo dosyć trudno wyobrazić. Ale kontakt z białoruskim odrodzeniowcem akademikiem A. Lisowskim, moim sąsiadem, czytanie Dudki i Smyka Bahuszewicza, łaknące czytanie poważnej literatury historycznej i filologicznej o Białorusinach i ich języku dokonały we mnie resztę. Trudności w niby tożsamym pojęciu „katolik i Polak” nie miałem żadnej ${ }^{10}$.

Ks. Stankiewicz założył w seminarium koło kleryków Białorusinów, do którego należeli: Józef Reszeć, Michał Szałkiewicz, Franciszek Oleszkiewicz, Andrzej Cikoto, Aleksander Augustynowicz, N. Kowalewski, W. Łuksza, Konstanty Stepowicz, J. Sławecki, Józef Daszuta, M. Boryk, Jan Lewkowicz, W. Romanowski, J. Dauksza. Większość z nich po pierwszej wojnie światowej wyraźnie deklarowała białoruską opcję narodowościową.

W 1912 r. dzięki ks. Lucjanowi Chwiećce w Katolickiej Akademii Duchownej w Petersburgu również powstało koło białoruskie, w którym poza inicjatorem znaleźli się: A. Cikoto, Paweł Piekarski, Stanisław Szyroki, Wincenty Godlewski, Jan Francuk, Ignacy Żołnierowicz ${ }^{11}$. W 1914 r. dołączyli doń: ks. Stankiewicz,

9 A. Stankievič, Biełaruski chrys'ciianski ruch, w: tenże, Z Boham da Biełarusi, Wilnia 2008, s. 479.

10 Tamże.

11 Tamże, s. 481. 
Wiktor Szutowicz, Karol Łupinowicz, Paweł Chomicz, Antoni Niemancewicz, M. Piotrowski ${ }^{12}$.

W czasie pierwszej wojny światowej działalność na niwie białoruskiej prowadził ks. K. Stepowicz, zakładając chór białoruski w Kluszczanach, głosząc tam kazania po białorusku oraz organizując 7 szkół białoruskich. W 1916 r. trafił do Korycina na Białostocczyźnie, o czym zapisał w swym dzienniku ${ }^{13}$. W Łapienicy pod Wołkowyskiem proboszczem był ks. Józef Hermanowicz (pseudonim literacki Wincuk Adważny). Po pierwszej wojnie światowej był proboszczem w Łużkach (powiat dziśnieński). Prężną działalność białoruską w czasie pierwszej wojny światowej prowadził ks. Władysław Tołłoczko, działający w Komitecie Pomocy Ofiarom Wojny w Wilnie. Poza tym pisał artykuły jako Adam Sołoduch w wileńskiej gazecie białoruskiej „Homan” oraz zabiegał o nabożeństwa i kazania w języku białoruskim w jednym z kościołów wileńskich oraz katechizację i spowiedź w języku białoruskim.

W dniach 25-27 stycznia 1918 r. w Wilnie odbyła się konferencja białoruska, w której uczestniczyli też księża Tołłoczko i Siemaszkiewicz. Z inicjatywy ks. Tołłoczko na Boże Ciało w 1918 r. (2 maja) Białorusini wyznania katolickiego oficjalnie wzięli udział w procesji, a chór dziecięcego przytułku „Zołak” śpiewał białoruskie pieśni religijne.

Wraz z powołaniem 12 grudnia 1918 r. na stanowisko biskupa wileńskiego Jerzego Matulewicza ożywiły się nadzieje na białoruskie życie Kościoła rzymskokatolickiego na ziemiach białoruskich. Ks. Tołłoczko przemawiał z tej okazji na bankiecie:

Świadomi Białorusini i księża-Białorusini w Diecezji Wileńskiej, jako synowie narodu, kierują swój głos synowski do Waszej Miłości Pasterskiej, prosząc o opiekę i pomoc we wszystkich potrzebach religijnych, kulturalnych i narodowych Białorusinów. [...] Kościół katolicki nie gardzi mową ludzi dzikich, więc nie pogardzi i naszą mową. Bez języka ojczystego naród nie może dobrze rozumieć swej mowy. Baz mała na całej Grodzieńszczyźnie to Białorusini, wielu Białorusinów i na wschodzie Diecezji Wileńskiej. W imieniu księży-Białorusinów Diecezji Wileńskiej życzę Waszej Miłości Pasterskiej długich lat życia, szczęśliwej pracy! ${ }^{14}$.

12 Tamże, s. 482.

13 K. Swajak, Dzieja majej myśli, serca i woli, Wilnia 1932.

14 A. Stankievič, Biełaruski chrys'ciianski ruch, s. 495. 
W dniach 24-25 maja 1917 r. w Mińsku odbył się zjazd księży Białorusinów. W komitecie organizacyjnym zjazdu znaleźli się znani już księża: Chwiećko, Godlewski, A. Astramowicz, F. Budźko i Cikoto ${ }^{15}$. W zaproszeniu na zjazd pisano w języku polskim:

Dziś zrzeszają się wszyscy. Łączą się ci, którzy są ożywieni jedną ideą i dążą do jednego celu, ażeby razem, wspólnemi siłami opracować zgodny plan działalności. Księża Białorusini jeszcze nie są zorganizowani, co wobec rozwoju ruchu białoruskiego w czasach obecnych może się fatalnie odbić na sprawie katolickiej i narodowej w naszym kraju. Dla omówienia spraw związanych z tym ruchem, Komitet organizacyjny zjazdu duchowieństwa białoruskiego zaprasza Wielmożnego Księdza na pierwsze posiedzenie zjazdu, które ma się odbyć we środę 24-go maja o godz. 7-ej wieczór w Mińsku (Kościół Katedralny m. № 6) ${ }^{16}$.

Jak wyjaśniał ks. Stankiewicz, było to taktycznym zagraniem, aby nie odstraszyć księży mało uświadomionych narodowo i przyciągnąć na zjazd możliwie najwięcej chętnych ${ }^{17}$. Na tym posiedzeniu wygłoszono referaty o ruchu białoruskim i jego stosunku do życia kościelnego oraz o Akcji katolickiej na Białorusi (ks. Stankiewicz), o akcji polityczno-narodowej duchowieństwa katolickiego na Białorusi w tych czasach i o utworzeniu partii katolickiej (ks. Godlewski), o społeczno-ekonomicznej akcji duchowieństwa (ks. Harasimowicz), o akcji oświatowej (ks. F. Abrantowicz), o akcji wydawniczej (ks. Chwiećko) ${ }^{18}$. Przewidziano powołanie pięciu komisji: życia kościelnego, polityczno-organizacyjnej, szkolnej, społeczno-ekonomicznej i wydawniczej. W obradach dopuszczano język polski i białoruski.

W zjeździe uczestniczyło około 30 duchownych ${ }^{19}$. W rezolucjach zjazdowych zapisano m.in. wprowadzanie kazań i dodatkowych nabożeństw w języku białoruskim ${ }^{20} .8$ października 1917 r. w Petersburgu z inicjatywy ks. Chwiećki

15 Biblioteka Białoruskiej Akademii Nauk w Mińsku, Dział Rękopisów (dalej: BBAN, Mińsk, DR), F. 23, op. 1, Materiały ks. Wiktora Szutowicza, List - zaproszenie na zjazd księży Białorusinów w Mińsku do ks. W. Szutowicza, k. 1.

16 Tamże.

17 A. Stankievič, Biełaruski chryścijanski, s. 106.

18 Tamże, s. 106-107; BBAN, Mińsk, DR, List - zaproszenie na zjazd.

19 A. Stankievič, Biełaruski chryścijanski, s. 106.

20 Tamże, s. 107-108. 
wydano pierwszy numer „Krynicy” - gazety katolickiej w języku białoruskim. W artykule redakcyjnym pisano:

Kochamy naszą Białoruś... i dlatego chcemy dla niej pracować i chcemy dać to, co możemy, chociaż jedną cegiełkę dołożymy do wielkiej budowli, jaka właśnie zaczęła się... Dla nas, synów chłopskich, droga jest każda piędź naszego kraju; zachować tę ziemię dla naszych włościan i osiągnąć z niej jak największą korzyść - to nasze wielkie zadanie... Teraz buduje się nasz kraj. Śpieszymy, aby pomóc w tej budowie, będziemy dawać wszystko, co zdołamy, a kierować nami będzie święta nauka Jezusa Chrystusa ${ }^{21}$.

Warto dodać, że aktywność księży Białorusinów wiązała się z niezwykłym ożywieniem na rzecz powstania niepodległej Białorusi, obwieszczonej 25 marca 1918 r. Niepewne losy ziem białoruskich w okresie 1918-1921 były wykorzystywane przez księży Białorusinów do szerzenia kazań białoruskich, gdzie to było tylko możliwe oraz do rozpowszechniania pisma „Krynica”, które stało się forum białoruskiej myśli chadeckiej. Sytuacja księży Białorusinów uległa radykalnej zmianie po traktacie w Rydze, podpisanym 18 marca 1921 r., w wyniku którego część ziem białoruskich znalazła się w państwie polskim. Jeszcze w okresie tzw. Litwy Środkowej, zajętej przez gen. Lucjana Żeligowskiego w październiku 1920 r., represje władz polskich dotknęły ks. Michała Piotrowskiego, proboszcza w Borunach. 28 czerwca 1921 r. aresztowano go i osadzono w więzieniu na Łukiszkach w Wilnie. 9 grudnia 1921 r. pisał w piśmie do biskupa wileńskiego Matulewicza:

26 czerwca 1921 r. władze administracyjne powiatu oszmiańskiego na polecenia sędziego ds. specjalnych Stulgińskiego w domu parafialnym w Borunach, gdzie jestem proboszczem, zrobiwszy najdokładniejszą rewizję, obwieściły mi, że jestem obwiniony z art. 129 Kodeksu Karnego za to, że niby dążę do przewrotu politycznego. I od razu, z użyciem siły, przewieziono mnie do Wilna, gdzie osadzono w areszcie. Oskarżenie to całkiem fałszywe: nie ma żadnych podstaw ani świadków. Naprowadziła go na mnie partia polityczna „endecja”, która widzi we mnie swego wroga. Prześladowanie mnie zaczęło się jeszcze w ubiegłym roku. Przyczyną jest to, że jestem księdzem katolickim, a nie „polskim”, jak tego chciała „endecja”, i że

21 Ad redakcji, „Krynica”, nr 1, 8 października 1917, s. 1. 
ultranacjonalistyczny program endecki jest dla mnie całkiem obcy. Podczas przyjścia bolszewików nie uciekałem, ale zgodnie z dyspozycją Waszej Ekscelencji wytrwałem na wyznaczonej pozycji. Oprócz tego, nie jestem Polakiem, tylko Białorusinem. Według poglądów „endecji”, w Polsce inny niż naród polski nie może ani korzystać z praw, ani istnieć. [...] Tymczasem dowodów winy nie ma i przesłuchania świadków wstrzymane. A ja zatrzymany w Wilnie, z parafii wyrzucony, nie mogę pełnić ani swych obowiązków, ani zdobywać potrzebnych na utrzymanie środków ${ }^{22}$.

Jeszcze w sierpniu 1919 r. dziekan oszmiański ks. Czesław Górski radził ks. Piotrowskiemu:

Proszę posłuchać mojej przyjacielskiej rady: ani rozmawiać po białorusku z ludem, a tym bardziej kazań po białorusku miewać nie radzę, bo lud rozumie po polsku i o to nie prosi. [...] Nie radzę, bo już wszystkie władze są zaalarmowane postępowaniem ks. proboszcza, oburzenie powstało ogromne. Policja śle skargi i ksiądz proboszcz może mocno pocierpieć. Ostrzegam i nie radzę $e^{23}$.

Prześladowania dotknęły także ks. Stepowicza, który był proboszczem w Zaświrzu. Tam znajdował się w areszcie domowym podczas wyborów do Sejmu Wileńskiego w 1922 roku ${ }^{24}$.

W 1920 r. prześladowano także ks. Jana Siemaszkiewicza, proboszcza w Ławaryszkach na Wileńszczyźnie, który chciał głosić kazania w języku białoruskim. W „Krynicy” opublikował wiersz o stosunku Polaków do niego:

Čamu tak złosna zakryčali?

I źwiazak kinuli sa mnoj

I sławu mnie ciapier staptali

Jak topčać ludzi podły hnoj!

Za što?

22 A. Stankievič, Biełaruski chrys'ciianski ruch, s. 521-522; A. Stankievič, Biełaruski chryścijanski, s. 159-160.

23 Cyt za: M. Moroz, „Krynica”. Ideologia i przywódcy białoruskiego katolicyzmu, Białystok 2001, s. 104-105.

24 A. Stankievič, Biełaruski chryścijanski, s. 161. 
Što ja pryznaŭsia da narodu,

S katorym doŭha žyŭ-uzros?

Što ja chaču, kab mieŭ swabodu,

Niadoli puty z siabie stros ${ }^{25}$.

W dniach 12-13 lipca 1921 r. odbył się w Wilnie zjazd białoruskiego duchowieństwa katolickiego, który zorganizowali księża Ildefons Bobicz, Tołłoczko i Stankiewicz. Wówczas zrodziła się myśl o założeniu organizacji zrzeszającej księży Białorusinów. Władze administracyjne odmówiły rejestracji statutu organizacji bez prawa odwołania się od tej decyzji. Księża Białorusini domagali się nauczania języka białoruskiego w Seminarium Duchownym w Wilnie, przekazania oddzielnego kościoła na potrzeby Białorusinów wyznania katolickiego oraz prawa do głoszenia kazań w języku białoruskim w parafiach, zamieszkałych w większości przez ludność białoruskąa ${ }^{26}$.

Swoistym przykładem konfliktu wokół języka kazań w parafiach z ludnością białoruską była tzw. sprawa żodziska ${ }^{27}$. W 1921 r. proboszczem w Żodziszkach został ks. Godlewski. W 1924 r. zaczął on głosić kazania w języku białoruskim, co spotkało się ze sprzeciwem części wiernych, w tym nauczycieli i urzędników. Msze, na których głoszono kazania w języku białoruskim, w żodziskim kościele cieszyły się większą frekwencją niż te z kazaniami w języku polskim. Biskup Matulewicz próbował tłumaczyć się z białoruskich kazań, stwierdzając, że zostały one wprowadzone w diecezji wileńskiej przez arcybiskupa Roppa,

[...] który w swym orędziu do duchowieństwa z r. 1917 nawet nakazuje, by w parafiach białoruskich obok polskich kazań miewano i białoruskie. [...] Ja pod tym względem nie wydawałem żadnych rozporządzeń natury

25 J. Siemaszkiewicz, Da maich daŭniejšych pryjacielaŭ Palakaŭ, „Krynica”, nr 7, 21 marca 1920, s. 3; polskie tłumaczenie: Dlaczego ze złością zakrzyczano: / I odwrócono się ode mnie / I sławę teraz mi zdeptano / Jak depczą ludzie podły gnój! / Za co? / Że się przyznałem do narodu, / Z którym przez lata żyłem-rosłem? / Że chcę by wolnym był, / Niedoli pęta z siebie zrzucił.

26 M. Moroz, „Krynica”, s. 108.

27 J. Tomaszewski, Zatarg o język kazań w Żodziszkach w kwietniu 1925 r., „Białoruskie Zeszyty Historyczne", 1996, nr 1 (5), s. 123-164; M. Moroz, Zatarg o język kazań w Żodziszkach, cd., „Białoruskie Zeszyty Historyczne”, 1998, nr 10, s. 124-165. 
ogólnej i nie wprowadzałem żadnych zmian, starałem się tylko podtrzymać stan rzeczy, jaki zastałem ${ }^{28}$.

W dniu 22 czerwca 1925 r. ks. Godlewski został aresztowany za kazanie wygłoszone w kościele św. Mikołaja w Wilnie z okazji rocznicy Białoruskiej Republiki Ludowej.

27 czerwca 1925 r. biskup Matulewicz zwrócił się do papieża Piusa XI o zwolnienie go z urzędu, na co 14 lipca otrzymał zgodę. Zastąpił go czasowo biskup sufragan ks. Kazimierz Michalkiewicz. Jednym z jego pierwszych posunięć było przeniesienie jesienią 1925 r. ks. dra Józefa Reszecia z posady profesora w Wileńskim Seminarium Duchownym na stanowisko prefekta w Seminarium Nauczycielskim w Białymstoku ${ }^{29}$. W 1925 r. ks. Reszeć wystosował protest do władz kościelnych w Rzymie oraz do władz świeckich i duchownych w Polsce przeciwko postanowieniom konkordatu, na mocy którego używanie języka białoruskiego w działalności kościelnej było uzależnione wyłącznie od decyzji episkopatu, a nie wiernych i duchowieństwa ${ }^{30}$.

29 września 1925 r. powtórnie aresztowano ks. Godlewskiego. Zarzucono $\mathrm{mu}$ przygotowanie zbrojnego, antypaństwowego wystąpienia i podburzanie ludności do nienawiści narodowościowej ${ }^{31}$. W wyniku procesu w marcu $1926 \mathrm{r}$. został on skazany na dwa lata twierdzy. Ks. Godlewski swoje stanowisko tłumaczył: „Każdy wie, że jestem Białorusinem, że pracuję nad odrodzeniem mojego narodu, ale żeby działać wbrew prawu sposobem rewolucyjnym - tego nigdy nie robiłem”32. Stwierdzał, że „budować fundament pod niezależność swej ojczyzny jest obowiązkiem każdego obywatela kraju - a właśnie nim chcę byćn"33.

8 września 1926 r. arcybiskupem wileńskim został Romuald Jałbrzykowski $^{34}$. Relacje z księżmi Białorusinami stały się jeszcze bardziej napięte. Biskup

28 Cyt. za: M. Moroz, „Krynica”, s. 129.

29 W. Choruży, Ks. dr Józef (Atanazy) Reszeć (1890-1958), „Białoruskie Zeszyty Historyczne", 1997, z. 7, s. 160.

30 Tamże.

31 M. Moroz, Zatarg o język, s. 131-135.

32 Cyt za: M. Moroz, „Krynica”, s. 160.

33 Tamże, s. 161.

34 A. Stankiewicz, Rodnaja mowa, s. 147. 
podzielał negatywne poglądy kapituły wileńskiej na kwestię białoruską w archidiecezji. Za jego bytności zaprzestano głoszenia kazań białoruskich w kościołach Brasławszczyzny i Dziśnieńszczyzny, przenoszono księży Białorusinów do parafii na zachodnich krańcach diecezji, np. ks. Szutowicza do Trzciannego, ks. Siemaszkiewicza do Janowa na Białostocczyźnie ${ }^{35}$.

10 grudnia 1928 r. arcybiskup Jałbrzykowski wydał rozporządzenie, skierowane do duchowieństwa i wiernych Archidiecezji Wileńskiej, w którym napisał:

[...] katolikom, a tembardziej kapłanom katolickim, do stronnictwa „Biełaruskaja Chryścijanskaja Demokracyja" ani należeć, ani w jakikolwiek sposób popierać nie wolno. Niewolno również katolikom prenumerować, czytać, rozpowszechniać, ani też w jakikolwiek sposób wspierać pisma, które nosi nazwę „Biełaruskaja Krynica”36.

Nie zgodził się również na kandydowanie do Sejmu ks. Adama Stankiewicza, który był posłem w latach 1922-1928.

Przykładem szczególnego potraktowania księży Białorusinów była rozprawa z zakonnikami z Drui. Klasztor oo. marianów w Drui powstał na podstawie reskryptu papieża Piusa XI z 23 lipca i 10 sierpnia 1923 r. Mieli oni odnowić stary budynek klasztorny, założyć szkołę i nowicjat dla Białorusinów ${ }^{37}$. Pod kierunkiem o. Andrzeja Cikoto do klasztoru w 1924 r. przybyli oo. Józef Hermanowicz i Kazimierz Smulko, w 1925 r. - Józef Daszuta, w 1926 r. - Fabian Abrantowicz. Dołączył do nich także wikary parafii drujskiej o. Witalis Chamionek. W 1924 r. do nowicjatu przyjęto dziewięciu chłopców. Przy klasztorze powstało gimnazjum, w którym uczyła się okoliczna młodzież. Represje władz wobec zakonników zaczęły się w 1928 r., kiedy w czerwcu o. Abrantowicza zesłano na misję do Charbinu. Przygotowania do usunięcia oo. marianów z Drui trwały przez kilka lat. W 1928 r. w „Dzienniku Wileńskim” ukazał się artykuł, w którym krytykowano białoruskie kazania w Drui ${ }^{38}$. W 1929 r., według Tadeusza Górskiego,

35 Ju. Turonak, Da historyi Drujskaga Maryjanskaga manastyra, w: tenże, Madernaja historyja Biełarusi, Wilnia 2006, s. 399.

36 A. Stankievič, Biełaruski chrys'ciianski ruch, s. 541.

37 Ju. Turonak, Da historyi, s. 395.

38 Propaganda białoruska w kościele, „Dziennik Wileński”, nr 287, 15 grudnia 1928, s. 2. 
zostały one zakazane ${ }^{39}$. W 1932 r. na misję do Charbina wysłano także o. Hermanowicza, a w 1933 r. - o. Cikoto. W czerwcu 1938 r. wysiedlono księży: Daszutę, Smulko, Chamionka i Kaszyrę, co spotkało się z medialnym protestem nawet prasy polskiej. Na łamach „Kurjera Wileńskiego” pojawiły się głosy w obronie oo. marianów:

Czym się zajmowali O. O. Marianie w Drui? Przede wszystkim prowadzili parafię. Byli księżmi i byli zakonnikami i funkcje te uważali dla siebie za najważniejsze. Jak już rzekłem, Druja leży blisko granicy bolszewickiej. O. O. Marianie cały swój autorytet, jaki mieli u ludności, rzucili na szale w walce z wszelkimi wpływami bolszewii. Dlatego też i głównie dzięki nim parafia drujska była uświadomiona o niebezpieczeństwie bolszewickim, była i jest wrogo ustosunkowana do Sowietów. [...] Poza tym O. O. Marianie utrzymywali w Drui gimnazjum. Gimnazjum było polskie, z polskim językiem nauczania, w gimnazjum nie słyszano słowa po białorusku nawet na pauzach. [...] Czy byli Białorusinami? Tak, do tego zawsze się przyznawali, często mówili z ludnością po białorusku, wyrośli z wiosek miejscowych i byli spokrewnieni z ich mieszkańcami. Czy jednak podsycali specjalnie ruch białoruski? Czy szerzyli specjalnie piśmiennictwo białoruskie? Czy występowali wrogo względem polskości? [...] Nazywali siebie Białorusinami, ale ich właśnie działalność dowodziła ludności, uczyła ją naocznie w sposób najbardziej przekonywujący, że Białorusini a Polska to jedno, że język polski i kultura polska, katolicka, zachodnia są dla nich bliskie i drogie; że nie należy słuchać podszeptów idących z zagranicy bolszewickiej, bo stamtąd wieje zguba. Za co więc wysiedlono oo. Marianów z Drui? Czy jako obywateli niebezpiecznych dla państwa polskiego?40

Jak wynika z działalności księży Białorusinów w II Rzeczypospolitej, byli oni patriotami swej ojczyzny, za którą uważali Białoruś, a nie Polskę. Ich losy po traktacie ryskim w $1921 \mathrm{r}$. w wielu przypadkach wskazują, że nadal pozostali przy swej opcji narodowościowej, co nie zawsze było postrzegane przychylnie przez władze duchowne i polityczne II Rzeczypospolitej. Traktowano ich często jako nacjonalistów (a nawet jako „komunistów” i „bolszewików”) oraz wrogów

39 T. Górski, Stosunek biskupa Matulewicza do spraw językowych diecezji wileńskiej 1918-1925, Rzym 1970, s. 65.

40 A. O., OO. Marianie wysiedleni z Drui, „Kurjer Wileński”, nr 159, 12 czerwca 1938, s. 7. 
państwa polskiego, za co spotykała ich niezasłużona kara aresztu, więzienia lub w najlepszymi układzie zesłania do polskich narodowościowo parafii lub na misje. Nie istniało samodzielne państwo białoruskie, a w Białoruskiej Socjalistycznej Republice Radzieckiej, podobnie jak w całym zSRR walczono z religią. Nie miał kto stanąć w ich obronie. Księża Białorusini właściwie byli zdani na siebie samych. Dopiero na początku lat dziewięćdziesiątych XX w., po rozpadzie ZSRR i powstaniu Republiki Białoruś, na fali odrodzenia narodowego i religijnego, przywrócono pamięć o księżach Białorusinach. Ich nazwiska pojawiły się w encyklopediach i słownikach, zaczęto wydawać ich twórczość, w tym religijną. Staraniem Jurasia Harbińskiego ukazała się praca o białoruskich działaczach religijnych $\mathrm{xx}$ wieku ${ }^{41}$. We wstępie do dzieł zebranych ks. Adama Stankiewicza nazwano go „dzwonnikiem niepodległości”, „jaskrawym przykładem ideowego białoruskiego działacza odrodzeniowego pierwszej połowy XX w." i patriotą ${ }^{42}$. Pamięć księży Jana Siemaszkiewicza i Kostantego Stepowicza uwieczniono w ich rodzinnej parafii pamiątkowymi głazami obok kościoła w Kluszczanach (rejon ostrowiecki w Republice Białoruś), na ich cześć urządzono konferencje popularno-naukowe i plenery malarskie. A język białoruski jest obecny w kościołach rzymskokatolickich na Białorusi oraz w wydawnictwach religijnych takich, jak np. „Nasza Wiera”.

Streszczenie: Po pierwszej wojnie światowej w granicach II Rzeczypospolitej znalazły się ziemie zamieszkałe w znacznej części przez ludność białoruską, zróżnicowaną wyznaniowo, w tym wyznania rzymskokatolickiego. Wywodzący się z niej księża katoliccy (m.in:: Kostanty Stepowicz, Jan Siemaszkiewicz, Wiktor Szutowicz, Wincenty Godlewski, Adam Stankiewicz, Władysław Tołłoczko), głosili kazania w języku białoruskim, co spotkało się ze sprzeciwem władz duchownych. Przed pierwszą wojną światową - jeszcze w Imperium Rosyjskim - związani oni byli z białoruskim pismem katolickim „Biełarus” (1913-1915) głoszącym idee białoruskiego odrodzenia narodowego. W II Rzeczypospolitej władze duchowne, zwłaszcza arcybiskup wileński Romuald Jałbrzykowski, nie patrzyły zbyt przychylnie na udział księży w białoruskim ruchu narodowym, zwłaszcza w Białoruskiej Chrześcijańskiej Demokracji, oraz na głoszenie przez nich kazań w języku bia-

41 Biełaruskiia relihijnyja dziejaczy XX stahoddzia, Minsk-Miunchien 1999.

42 A. Waszkiewicz, A. Paszkiewicz, Zwanar niezależnas'ci, w: A. Stankiewicz, Z Boham da Biełarusi, Wilnia 2008, s. 17, 29. 
łoruskim. Mimo że byli patriotami swego kraju, przez władze duchowne traktowani byli jako nacjonaliści, a nawet komuniści. Za białoruską opcję narodową spotykały ich prześladowania ze strony władz polskich: rewizje, aresztowania, więzienie oraz przeniesienia do innych - polskojęzycznych - parafii. Można stawiać pytania, dlaczego w Polsce międzywojennej, zróżnicowanej narodowościowo księży Białorusinów traktowano jak wrogów państwa polskiego, dlaczego zakazywano im kazań w języku miejscowej ludności, dlaczego nie pozwalano współpracować z białoruską prasą chadecką („Krynica”, „Biełaruskaja Krynica”, „Chryścijanskaja Dumka”) wychodzącą w Wilnie, dlaczego przenoszono ich na misje albo do innych, obcych im parafii. Ci, którzy zdołali przeżyć drugą wojnę światową i znaleźli się w nowych granicach Polski, skrzętnie ukrywali swą narodowość, służąc wiernie Kościołowi katolickiemu, m.in. ks. Jan Siemaszkiewicz.

Słowa kluczowe: II Rzeczypospolita, Białorusini, patriotyzm, Kostanty Stepowicz, Jan Siemaszkiewicz, Wincenty Godlewski, Adam Stankiewicz

\section{Bibliografia}

Biblioteka Białoruskiej Akademii Nauk w Mińsku, Dział Rękopisów, F. 23, op. 1, Materiały ks. Wiktora Szutowicza, List - zaproszenie na zjazd księży Białorusinów w Mińsku do ks. W. Szutowicza.

A. O., oo. Marianie wysiedleni z Drui, „Kurjer Wileński”, nr 159, 12 czerwca 1938.

Ad redakcji, „Krynica”, nr 1, 8 października 1917.

Biełaruskiia relihijnyja dziejaczy XX stahoddzia, Minsk-Miunchien 1999.

Choruży W., Ks. dr Józef (Atanazy) Reszeć (1890-1958), „Białoruskie Zeszyty Historyczne”, 1997, z. 7 .

Górski T., Stosunek biskupa Matulewicza do spraw językowych diecezji wileńskiej 19181925, Rzym 1970.

Jan z-pad Łasosny, Garadzienski biełaruski gurtok 1913 h. Uspaminy, „Krywicz”, nr 1 (7).

L. S.-Sz., Uspaminy ab „Horadzienskim hurtku Biełaruskaj Moładzi”, „Studenskaja dumka", 1925, nr 3, 4 .

Moroz M., „Krynica”. Ideologia i przywódcy białoruskiego katolicyzmu, Białystok 2001.

Moroz M., Zatarg o język kazań w Żodziszkach, cd., „Białoruskie Zeszyty Historyczne”, 1998, nr 10.

Nawina A. , Na darozie da nowaha życ'cia, „Maładaja Biełarus”, 1912, nr 1.

Poczopko B., „Biełarus” (Ze wspomnień redaktora), „Przegląd Wileński”, nr 16, 11 października 1925.

Propaganda białoruska w kościele, „Dziennik Wileński”, nr 287, 15 grudnia 1928. 
Siemaszkiewicz J., Da maich daŭniejšych pryjacielaŭ Palakaŭ, „Krynica”, nr 7, 21 marca 1920.

Stankievič A., Biełaruski chryścijanski ruch, Vilnia 1939.

Stankievič A., Biełaruski chrys'ciianski ruch, w: tenże, Z Boham da Biełarusi, Wilnia 2008. Stankiewicz A., Rodnaja mowa u'swiatyniach, Wilnia 1929, S. 72-75.

Swajak K., Dzieja majej myśli, serca i woli, Wilnia 1932.

Tomaszewski J., Zatarg o język kazań w Żodziszkach w kwietniu 1925 r., „Białoruskie Zeszyty Historyczne", 1996, nr 1 (5).

Turonak Ju. , Z paczynu prałata S'ciafana Danisiewicza, w: tenże, Madernaja historyja Biełarusi, Wilnia 1929.

Turonak Ju., Da gistoryi Drujskaga Maryjanskaga manastyra, w: tenże, Madernaja historyja Biełarusi, Wilnia 2006.

Waszkiewicz A., A. Paszkiewicz, Zwanar niezależnas'ci, w: A. Stankiewicz, Z Boham da Biełarusi, Wilnia 2008. 